\title{
Epehólyag-agenesia. Epekövességet utánzó ritka rendellenesség egy felnőtt nőben
}

\author{
Molnar Călin dr. ${ }^{1}$ - Sárközi Tibor dr. ${ }^{2}$ - Kwizera Cedric dr. ${ }^{3}$

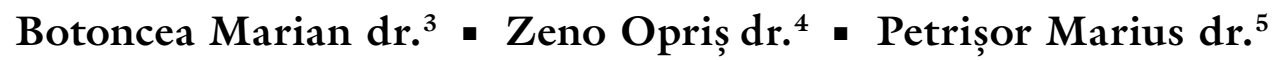 \\ Grigorescu Bianca Liana dr. ${ }^{6}$
}

\author{
${ }^{1}$ Marosvásárhelyi Orvosi, Gyógyszerészeti, Tudomány- és Technológiai Egyetem, Sebészeti Osztály, \\ Marosvásárhely, Románia \\ ${ }^{2}$ Maros Megyei Sürgősségi Kórház, Aneszteziológia és Intenzív Terápia Osztály, Marosvásárhely, Románia \\ ${ }^{3}$ Maros Megyei Sürgősségi Kórház, I. Sebészeti Klinika, Marosvásárhely, Románia \\ ${ }^{4}$ Maros Megyei Sürgősségi Kórház, Radiológiai Osztály, Marosvásárhely, Románia \\ ${ }^{5}$ Marosvásárhelyi Orvosi, Gyógyszerészeti, Tudomány- és Technológiai Egyetem, \\ Szimulációs és Gyakorlati Készségfejlesztő Központ, Marosvásárhely, Románia \\ ${ }^{6}$ Marosvásárhelyi Orvosi, Gyógyszerészeti, Tudomány- és Technológiai Egyetem, Élettani Tanszék, \\ Marosvásárhely, Románia
}

\begin{abstract}
Az epehólyag-agenesia ritka, a biliaris rendszer embriológiai hibája miatt kialakult veleszületett elváltozás. Az esetek többségében tünetmentes, más esetekben az epekólika tüneteit utánozza. Betegünk 72 éves kaukázusi nő. Anamnézisében magasvérnyomás-betegség, illetve magas koleszterinszint szerepelt, melyekre vérnyomáscsökkentő, illetve koleszterinszint-csökkentő kezelést kapott. Felvételére az epekólika tüneteinek megjelenése miatt került sor. Laparoszkópos mütéten esett át, mely alátámasztotta a végleges diagnózist. E ritka eset kapcsán bemutatjuk megközelítésünket, valamint az orvosi szakirodalom rövid áttekintését. A sebésznek intraoperatívan el kell döntenie, hogy egy lehetséges ectopiás epehólyagot keres, vagy tovább vizsgálja az esetet képalkotó eljárások segítségével. Az epehólyagagenesia ritka állapot, mellyel a sebésznek számolnia kell. Azokban az esetekben, amikor az epekövesség tünetei nem meggyőzőek, a műtét elkerülése végett a legjobb kiegészítő képalkotó eljárás a mágnesesrezonancia-kolangiopankreatográfia.
\end{abstract}

Orv Hetil. 2019; 160(38): 1510-1513.

Kulcsszavak: epehólyag-agenesia, laparoszkóp, cholecystectomia

\section{Gallbladder agenesis - A rare congenital anomaly mimicking cholelithiasis in an adult woman}

Gallbladder agenesis is a rare congenital malformation due to an embryological defect of the biliary system. In most cases it is asymptomatic, but it can also mimic biliary colic. We report the case of a 72 -year-old Caucasian woman with a medical history of cardiovascular disease and hypercholesterolemia, under cholesterol-lowering and hypotensive treatment, who presented symptoms suggesting biliary colic. She underwent laparoscopic surgery that confirmed the final diagnosis. We present our approach in this rare case as well as a brief review of medical literature. The surgeon should decide intraoperatively whether to continue and search for a possible ectopic gallbladder or investigate further with imaging studies. Gallbladder agenesis is a rare condition that the surgeon must be aware of. In the cases of inconclusive or indirect signs of cholelithiasis, the best approach is complementary imaging investigations such as magnetic resonance cholangiopancreatography in order to avoid surgery.

Keywords: gallbladder agenesis, laparoscopy, cholecystectomy

Molnar C, Sárközi T, Kwizera C, Botoncea M, Zeno O, Petrişor M, Grigorescu BL. [Gallbladder agenesis - A rare congenital anomaly mimicking cholelithiasis in an adult woman]. Orv Hetil. 2019; 160(38): 1510-1513.

(Beérkezett: 2019. április 12.; elfogadva: 2019. május 10.) 


\section{Rövidítések}

$\mathrm{CT}=$ (computed tomography) számítógépes tomográfia; $\mathrm{ERCP}=$ (endoscopic retrograde cholangiopancreatography) endoszkópos retrográd kolangiopankreatográfia; $\mathrm{MRCP}=$ (magnetic resonance cholangiopancreatography) mágnesesrezonancia-kolangiopankreatográfia

Az epehólyag-agenesia ritka állapot, mely $100000 \mathrm{em}$ berből 10-65 személyt érint; főleg nókben jelentkezik (arány $3: 1$ ) [1]. A veleszületett agenesia tulajdonképpen egyenlő arányban jelenik meg nókben és férfiakban, viszont az epekólika vagy epekövesség tünetei gyakrabban jelentkeznek nők esetében [2]. Jelentett incidenciája $0,007-0,027 \%$ mútéti sorozatok esetén, és emelkedett volt boncolások alkalmával $(0,04-0,13 \%)$ [3]. Ez a ritka rendellenesség a méhen belüli élet első hónapjainak végén jelentkezik. Az epehólyag a májdiverticulumból és a májprimordiumból alakul ki. Embriológiailag akkor kezdődik, amikor a cisztikus bimbó az előbél caudalis részéból fejlődik ki, és a septum transversumba burjánzik bele. A bimbónak két része különíthetô el, az egyik az epehólyag és a ductus cysticus, a másik pedig a máj mirigyes szerkezetének fejlődésében vesz részt.

Klinikai tanulmányok alapján az epehólyag-agenesia három részre osztható:

1. Perinatalis végzetes vagy nem végzetes többszörös magzati elváltozások által okozott halál, mint például végbélnyíláshiány, patkóbél-elzáródás, epeút-elzáródás, kamrai septumdefektus, bélcsavarodás, epevezeték-ciszta és a közös epevezeték tágulata.

2. Szimptomatikus.

3. Aszimptomatikus $[3,4]$.

A páciensek többségénél életkoruk 4 . vagy 5 . évtizedében kezdenek megjelenni a tünetek. A betegek krónikus, a jobb hypochondriumban fellépő fájdalom, emésztési zavarok, sárgaság, zsíros étel iránti intolerancia miatt panaszkodnak. Ezek a tünetek a heveny epehólyag-gyulladásra vagy epekólikára jellemzőek, tévesen értelmezve epehólyag-gyulladásnak vagy krónikus epehólyag-gyulladásnak tekinthetik $[5,6]$.

\section{Esetismertetés}

Egy 72 éves kaukázusi nő kórtörténetében szív-ér rendszeri megbetegedés, illetve magas koleszterinszint szerepelt, melyekre vérnyomáscsökkentő és koleszterinszintcsökkentő kezelést kapott. Felvételére visszatérő, a jobb hypochondriumban jelentkező fájdalmak, illetve zsíros étel fogyasztása után fellépő hányinger miatt került sor. A fájdalom intermittáló, éles és hátba sugárzó volt. A páciens a székelési szokások megváltozását, vizelési panaszokat, lázat, a széklet, illetve vizelet jellegének változásait tagadta. Kórtörténetéből megemlítendő a végbélmútétje, melynek posztoperatív szakasza zavartalan volt, illetve a hólyagsüllyedés-mútétje. Az alkoholfogyasztást és a dohányzást tagadta. A fizikális vizsgálat során, fizio- lógiás kardiorespiratorikus paraméterek mellett, a beteg a hasfal jobb oldali felső kvadránsában jelzett fájdalmat. Laboratóriumi vizsgálataiban normális fehérvérsejtszámot $(5890 \mathrm{sejt} / \mathrm{\mu l})$ találtunk, a vörösvértestek átlagos térfogata enyhén csökkent $(78,8 \mathrm{fl})$, a vörösvértestre számított hemoglobinmennyiség 27,7 pg volt, s enyhén emelkedett volt a vörösvértestek eloszlási szélessége (15\%), ami enyhe anaemiára utalt. Az anyagcsere szempontjából a koleszterinszint emelkedett $(262,22 \mathrm{mg} / \mathrm{dl})$ volt. A hasi ultrahang az epehólyag falának megvastagodását $(4,7 \mathrm{~mm})$, több epekő jelenlétét tette láthatóvá, intra-, illetve extrahepaticus epevezeték-tágulat nélkül. A páciensnek a cholelithiasis diagnózisát állítottuk fel, és elójegyeztük egy laparoszkópos epehólyag-eltávolító mútétre a marosvásárhelyi Megyei Sürgősségi Kórház 1-es Számú Sebészeti Klinikáján. Két hét elteltével átesett az általános altatásban végzett laparoszkópos mútéten. Csupán két trokárt vezettünk be (egy $10 \mathrm{~mm}$ vastagságú, köldök alatti optikai, illetve egy $5 \mathrm{~mm}$ vastagságú manipulációs trokárt a jobb hypochondrium szintjén). A hasüreg vizsgálata során máj körüli adhézió volt látható, viszont epehólyag, illetve epevezeték nem volt azonosítható. A közös epevezeték tágultnak (18,5 $\mathrm{mm}$ ) látszott (1.ábra), valószínúleg egy epehólyaghiány miatt kialakult kompenzatorikus folyamat miatt. Az öszszenövéseket megszüntettük, és ectopiás epehólyag után kutattunk. Anatómiai elváltozást nem találván, a máj alá helyezett dréncső után a mútétet konvertálás nélkül fejeztük be. A posztoperatív időszak eseménymentesen zajlott, a páciens teljes felépülésével. A beteg mágnesesrezonancia-kolangiopankreatográfiás (MRCP) kivizsgáláson esett át, mely alátámasztotta az epehólyag hiányát. Más anatómiai elváltozást nem találtak (2. ábra).

Ectopiás epehólyagot keresve megvizsgáltuk a hasüreget, de más anatómiai elváltozást nem találtunk (3. ábra). Úgy döntöttünk, hogy a kimerítő dissectio fölösleges, és néha epeúti, illetve májlaesiókhoz vezethet.



1. ábra Kompenzációs epevezeték-tágulás 1) Jobb májvezeték, 2) bal májvezeték, 3 ) közös májvezeték 


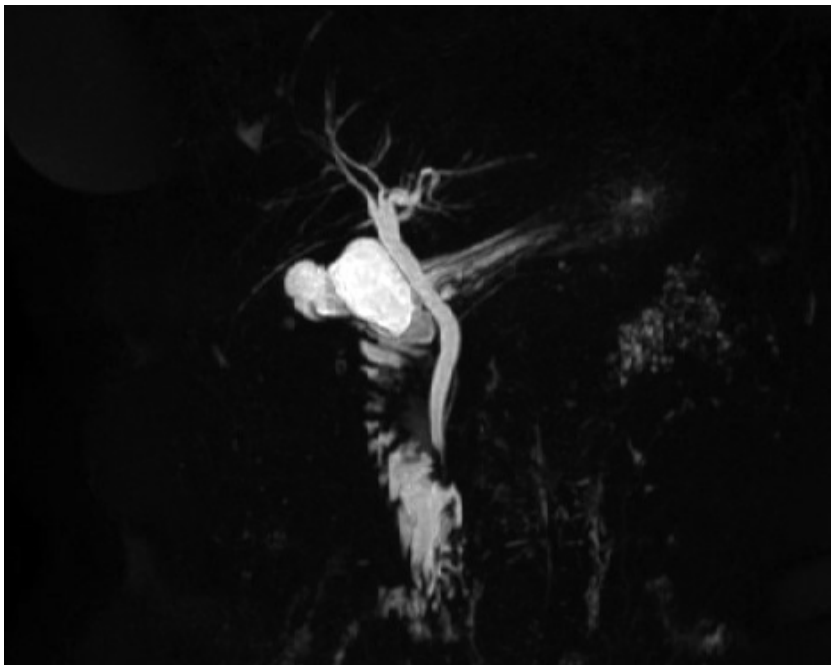

2. ábra

| Mágnesesrezonancia-kolangiopankreatográfia

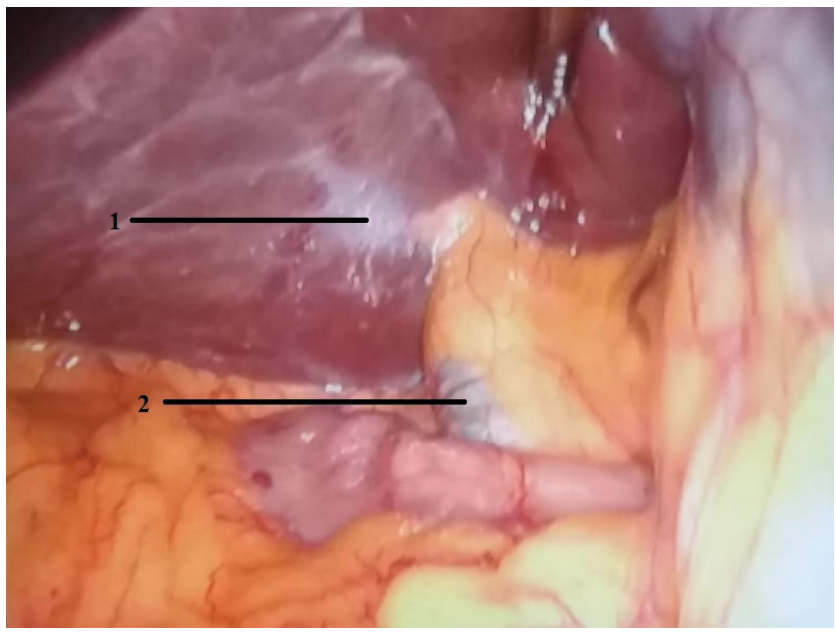

3. ábra

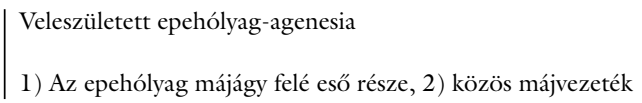

\section{Megbeszélés}

A veleszületett epehólyag-agenesia ritka állapot, melynek végső diagnózisát mưtét alatt állítják fel. Először Lemery és Bergman írták le 1701 és 1702-ben. Azóta néhány elszigetelt epehólyaghiány-eset került leírásra $[7,8]$.

Bennion és munkatársai 1988-ban az epehólyag-agenesia klinikai bemutatása során három típust különböztettek meg: 1) többszörös magzati elváltozással rendelkező betegek, 2) tünetmentes páciensek, illetve 3) tünetekkel rendelkező páciensek [7]. Az utóbbi évek során Bennion osztályozása egyszerúsítve lett l-es típusra (tünetekkel rendelkező), illetve 2-es típusra (tünetmentes) és $1 / \mathrm{b}$ altípusra, mely magában foglalja a vele járó végzetes veleszületett elváltozásokat [7]. Az epehólyag-agenesia a sebészi és klinikai megközelítés fontosságát támasztja alá. A mútét előtti diagnózis nehezített, mivel utánozza az epekólika tüneteit. A tünetekkel rendelkező páciensek az esetek többségében egy zsírban gazdag étkezés után a has jobb felső kvadránsában jelentkező, illetve epigastrialis fájdalomról panaszkodtak, mely a jobb lapocka irányába sugárzott, illetve hányinger, hányás, étvágytalanság is társult a tünetekhez. A szakirodalomban kevés epehólyaghiány-esetet jelentettek, mely sárgasággal vagy májmúködési zavarral társult volna, akárcsak az epehólyag jelenlétében [8]. Kórélettani magyarázata ennek a klinikai bemutatónak az Oddiféle záróizom múködési zavarához és az epe mozgászavarához köthető. A görcsoldó kezelés miatt szűnő fájdalom alátámasztja ezt az elméletet [9].

A legtöbb esetben az epehólyag hiányának diagnózisa intraoperatíve történik. Az epekólikás betegeknél a hasi ultrahang a standard kivizsgálási módszer. Epehólyagagenesia esetén az akusztikus árnyék tévesen epekőként diagnosztizálható (lehetséges múhibák, bélgáz jelenléte, máj alatti hashártya-összenövés vagy akár periportalis szövet miatt) [10]. A mi esetünkben a máj körüli hashártya-összenövések okozhatták az epekövesség téves diagnózisát. Azon esetekben, amikor az epehólyag nem látható, a differenciáldiagnózis egy összehúzódott vagy zsugorodott hólyaggal szemben a WES-hármas (wall, echo, shadow - fal, visszhang, árnyék) alapján állítható fel [7]. Az irodalomban a legtöbb esetben a legfőbb téves diagnózis oka a megvastagodott vagy zsugorodott hólyag [11]. Ez az oka annak, hogy 2010-ben Malde közzétett egy epehólyag-agenesiai diagnosztikai és menedzsmentalgoritmust, mely imitálja az epekólikát [11]. Ezen algoritmus szerint a diagnózis felállításához MRCP, komputertomográfia (CT) és endoszkópos retrográd kolangiopankreatográfia (ERCP) szükséges. Az algoritmus elóírásai ellenére az MRCP az epekólikával rendelkező pácienseknél nem rutinszerúen végzett kivizsgálás, így a legtöbb esetben a mútét alatt állítható fel a pontos diagnózis. Habár az epehólyag-agenesia tünetei a 4., illetve 5. évtizedben jelentkeznek, a mi esetünkben későn, a 7. évtizedben mutatkoztak, és úgy gondoljuk, hogy az epekólika tüneteiért az Oddi-záróizom múködési zavara, a megnövekedett ductus choledochus nyomás, illetve a máj körüli összenövések felelősek.

$\mathrm{Az}$ évek során állandó vita keletkezett e patológia megfelelő módjának megoldására: „Át kellene konvertálni a laparoszkópos mútétet nyílt mútétté?" Egyfelől sok sebész azt állította, hogy nem szükséges konvertálni, mivel laparoszkóp segítségével is jól megvizsgálható a hasüreg [11], másrészt a vizsgálat során kizárható egy ectopiás epehólyag, a májon belül, bal oldalon, a kiscseplesz szintjén, ligamentum falciforme, illetve retroperitonealisan [8]. Egy másik sebészcsoport a konvertálás mellett döntött. A nyílt mútét ebben az esetben máj- és epevezeték-laesióval, a vékonybél és a májerek laesiójával járhat, mely az intrahepaticus, illetve retrohepaticus tér preparálása során keletkezhet [5]. Mi az első sebészi csoportot támogatjuk, és a mi esetünkben a laparoszkópos műtétet követő MRCP volt a legjobb megoldás. Nem ajánljuk a 
májhilus kipreparálását, sem a nyílt mütétre való konvertálást, mely többszörös szövődményekhez vezethet. Az esetek többségében az epekólika tünetei epehólyaghiány esetén, mütét után enyhülnek; a konzervatív kezelés simaizom-relaxánsokkal javallt, mely alátámasztja a tünetek megjelenéséért felelős Oddi-záróizom spasmusát. Egyes esetekben a mütét utáni fájdalom megszűnésének magyarázata az összenövések megszüntetésére vezethető vissza [7]. A mi esetünkben ez lehetne a magyarázat. A laparoszkópos mütétet követő harmadik napon a beteg tünetmentesen távozott.

\section{Következtetés}

Az epehólyag hiánya ritka állapot, mely utánozza az epekólikát vagy a tünetes epekövességet. Egyes esetekben, amikor az epehólyag gyengén körülhatárolt, a mútét előtti ultrahang-kivizsgáláson gondolnunk kell ezen differenciáldiagnózisokra. Mivel a nyílt műtét nem zárja ki a szövődményeket, a legjobb megközelítés a mütét előtti MRCP. Abban az esetben, ha az epehólyag hiányára nem gyanakodnak, laparoszkópos mútét ajánlott, melyet MRCP vagy ERCP követ.

\section{Beleegyezés}

A pácienstől írásos beleegyezést kaptunk az esetismertetés közzétételéhez, beleértve a képeket is. A beleegyezés másolata kérésre megtekinthető a folyóirat főszerkesztőjénél.

Anyagi támogatás: A szerzők anyagi támogatásban nem részesültek.

Szerzôi munkamegosztás: M. C.: Adatelemzés és értelmezés, a kézirat áttekintése, a mütét végrehajtása. S. T.: Adatgyưjtés, fordítás, adatelemzés. Z. O.: Radiológiai képalkotás, illetve értelmezés. K. C., B. M.: Adatelem- zés. P. M.: A kézirat szerkesztése. G. B. L.: Adatelemzés és a közlemény megírása. A cikk végleges változatát valamennyi szerző elolvasta és jóváhagyta.

Érdekeltségek: A szerzőknek nincsenek érdekeltségeik.

\section{Irodalom}

[1] Moon AM, Hamilton Howe J, McGinty KA, et al. Gallbladder agenesis mimicking cholelithiasis in an adult. Radiol Case Rep. 2018; 13: 640-643.

[2] Bahraini A, Odom JW, Talukder A. A case report of a patient with gallbladder agenesis resulting in a common bile duct injury. Int J Surg Case Rep. 2018; 51: 99-101.

[3] Bianco G, Frongillo F, Salvatore A, et al. Gallbladder agenesis: a case report and brief review. Ann Hepatobiliary Pancreat Surg. 2018; 22: 292-295.

[4] Takano Y, Hoshino M, Iriyama S, et al. Gallbladder agenesis with hepatic impairment: a case report. BMC Pediatrics 2018; 18: 360.

[5] Salazar MC, Brownson KE, Nadzam GS, et al. Gallbladder agenesis: a case report. Yale J Biol Med. 2018; 91: 237-241.

[6] Haghighatafshar M, Amirkhani Z, Ghaedian T. Role of hepatobiliary scintigraphy in the diagnosis of gallbladder agenesis; a case report and a brief review of literature. Middle East J Dig Dis. 2018 ; 10: 109-113.

[7] Rajkumar A, Piya A. Gallbladder agenesis: a rare embryonic cause of recurrent biliary colic. Am J Case Rep. 2017; 18: 334338.

[8] Tagliaferri E, Bergmann H, Hammans S, et al. Agenesis of the gallbladder: role of clinical suspicion and magnetic resonance to avoid unnecessary surgery. Case Rep Gastroenterol. 2016; 10: 819-825.

[9] Scobie JL, Bramhall SR. Congenital agenesis of the gallbladder: a UK case report. Oxf Med Case Reports 2016; 8: 176-178.

[10] Chandio A, Javaid A, Mustafa S, et al. Biliary tract variations and its correlation with clinical presentations. Surgery Curr Res. 2014; 4: 210 .

[11] Pipia I, Kenchadze G, Demetrashvili Z, et al. Gallbladder agenesis: a case report and review of the literature. Int J Surg Case Rep. 2018; 53: 235-237.

(Sárközi Tibor dr.,

Ro-455200 Zsibó, Udvarhelyi u. 30., Szilágy megye, Románia e-mail: tiborsarkozi@yahoo.com)

\section{A rendezvények és kongresszusok híranyagának leadása}

a lap megjelenése előtt legalább 40 nappal lehetséges, a 6 hetes nyomdai átfutás miatt. Kérjük megrendelőink szíves megértését.

A híranyagokat a következő címre kérjük:

Orvosi Hetilap titkársága: edit.budai@akademiai.hu

Akadémiai Kiadó Zrt. 